\title{
Towards effective advertising regulation: A comparison of UK, Australian and South African schemes
}

\author{
D. Harker* \\ University of the Sunshine Coast Faculty of Business, \\ Locked Bag 4, Maroochydore South, Queensland 4558, Australia \\ dharker@usc.edu.au \\ S. Cassim \\ University of Natal, Durban, Republic of South Africa \\ Received November 2002
}

\begin{abstract}
The regulation of advertising is a controversial and difficult process, and many schemes around the world opt for a selfregulatory approach to curb unacceptable advertising. However, when schemes are established or reformulated, most countries learn from other, more established, regimes. Whilst Australia and South Africa commenced the advertising self-regulation (ASR) process at similar times and based their systems on the UK model, two attempts have been made in Australia over the past three decades to produce more acceptable ads, whilst South Africa's system has endured in its original form. This paper reviews the ASR systems in these three countries, using a macro framework for analysis which contextualises advertising in society. The systems have the fundamental process of handling complaints about advertising in common, however there are advantages and disadvantages of each and these are discussed with a view to providing some guidance for Australia's fledgling, reformulated, system. Important insights for the development of regulation of advertising are presented.
\end{abstract}

*To whom all correspondence should be addressed.

\section{Introduction}

Advertising plays a significant role in the free-market economy by contributing toward the development of new technology, new ideas and new products (Woker, 1999; Boddewyn, 1992). Advertising can also be credited with promoting informed decision-making by providing information. In a free-market environment however, where marketers vie for consumer attention, advertisers may push the limits of what is considered acceptable in advertising (Mittal, 1994). Hence, advertising has been blamed for a long list of social ills and is alleged to camouflage a deeper social malaise caused by unemployment, a breakdown in family values, morals and religious faith (Freedom of Commercial Speech Trust, 1999). This environment, where competition can be manipulative, provides the rationale for strict regulation of the marketplace (Woker 1999; Harker 1998). Controls are generally put into place to protect society from deceptive, misleading or harmful advertising and most developed countries have established programs of self-regulation in place, which complement their legal systems. Established practice in the field of developing advertising self-regulation (ASR) around the world (such as in Australia) has been to learn from other countries with established systems of ASR in place (such as the UK and South Africa).

Whilst Best (1997:223) suggests that 'only ethical people can make ethical choices', many cynical observers of advertising in society would argue that advertisers are increasingly unethical in their attempts to reach their target markets. The activity has been described as pervasive (Drake, 1988:21), intrusive (Blakeney \& Barnes, 1982:35) and, at times, pernicious. In the same vein, Mittal (1994) has suggested that the purveyors of the art have been known to be mischievous in their commercial role. Globally, we are told, developed and developing societies are bombarded by 'several hundred millions of different advertisements' which are published and broadcast each year (Boddewyn, 1992:22). On the one hand, these figures are testament to the importance of this, the most visible, element of the marketing mix (Boddewyn, 1989:22), however they can also be viewed as further evidence that some members of society may need to be protected as some advertising can be harmful.

A small proportion of advertisements are offensive, false, misleading, unfair, or socially irresponsible, or they are perceived as such by the general public. So, when this is the case, a structure needs to be in place in order to provide protection to all parties. To complement their legal systems, developed countries have established programs of regulation which, in the main, are operated on a self-regulatory basis, where the industry is responsible for controlling the conduct of its own members. However, the recent breakdown in Australia of one of the world's longest established advertising self-regulatory systems, and the introduction of a new system, highlights the problems associated with providing effective protection for society from unacceptable advertising (Media Council of Australia, 1996; Strickland, 
1996). Comparing the Australian situation with that of South Africa, a country outside of that region that has established an enduring system of ASR for more than thirty years, and also the UK's system, which has been the model for many established schemes around the world, will make a significant contribution to knowledge in this important area.

The achievement of acceptable advertising through selfregulatory systems is a topic that has been debated spasmodically in leading marketing journals for over twenty years. This extant literature can be classified into two key streams, the first provides a significant, although somewhat descriptive, body of knowledge of ASR in general and examines, for example, how various schemes function around the world (Neelankavil \& Stridsberg, 1980; Miracle \& Nevett, 1987; Boddewyn, 1988 \& 1992). The second stream is more prescriptive and provides normative guides for regulators and advertisers to assist in developing effective ASR programs. Indeed, research studies have provided seven tests (Moyer \& Banks, 1977), five activities (LaBarbera, 1980), five recommendations (Armstrong \& Ozanne, 1983), six tasks (Boddewyn, 1985), and fifteen rules (Wiggs, 1992) as normative guides for advertisers in developing ASR programs.

Despite these research themes, little is known about how acceptable advertising can be defined and monitored. Thus, in the overall context of advertising regulation, this article has two objectives: first, to present and discuss the key variables associated with acceptable advertising. Second, to use these variables as a framework to analyse the way advertising is regulated in the UK, Australia and South Africa. This analysis will greatly assist the continued development of effective ASR in all of these countries.

\section{Regulation, self-regulation and advertising}

The parent body of literature for this research is social control (Streeck \& Schmitter, 1985) and, in particular, regulatory theory, incorporating collective action and group decision-making, in the context of advertising.

Regulation is primarily concerned with social control and, in the context of this article, specifically the interaction between 'authority' and 'exchange' (Harris \& Carman, 1983). The authority of the state is used to protect those involved in the exchange process. The concept of exchange is at the heart of the marketing process and, when dealing with advertising in a society, those people who are often exposed to increasing amounts of advertising are often those least able to protect themselves when that advertising oversteps the boundaries of acceptability. The item exchanged in advertising is information, and problems arise when misleading, deceptive or offensive information is communicated to the marketplace, in other words unacceptable advertising.

Whilst research in this area is problematic, scholars such as Wotruba (1997) have issued the challenge to researchers, suggesting that the literature on self-regulation in general has little empirical flavour, does not inform about the effectiveness of schemes, does not enlighten about what types of programs are more effective than others, under what conditions and for what interested stakeholders. Given this challenge, it is not surprising that there are cynics among researchers when discussing the merits or demerits of industry self-regulation; indeed, some researchers have warned that self-regulation is like 'letting the lunatics run the asylum' (Ducret, 1991:76).

Whilst ASR is an attractive option for advertisers, a prerequisite to continued operation and, little direct government involvement, is the concept of 'collective action'. Collective action has three main purposes (Harris \& Carman, 1984:46); first to realise economies of scale in production, second to internalise the benefits of productive actions and, finally, to change the balance of power between participants in the exchange process. However, when focusing on the marketing exchange process, and in particular the activity of advertising, unless the vast majority of advertisers are committed to, and involved in, the ASR scheme, continued self-regulation will be short-lived.

Gupta and Lad (1983:419) suggested that industry selfregulation will only take place if the firms in the industry, the advertisers, decide to cooperate with each other. Similarly, where the ASR scheme incorporates a national tripartite system (Boddewyn, 1992:9; Sinclair, 1992:3) and the advertisers, agencies and media are involved in the process, cooperation will be significantly enhanced. This collective action, which grows out of the need to regulate, succeeds in spreading the decision-making responsibility across a group. Although group decision-making has received a number of criticisms over the years (wasting of time, evading individual responsibility, producing conformity and compromise [Ofner, 1959]), the benefits of quality and acceptance of group decisions still prevail (Jewell \& Reitz, 1981).

\section{Acceptable advertising - the key variables}

The literature in the area suggests a conceptual framework of acceptable advertising, which can be applied to analyse the regulation of advertising in developed countries. The framework is shown at Figure 1.

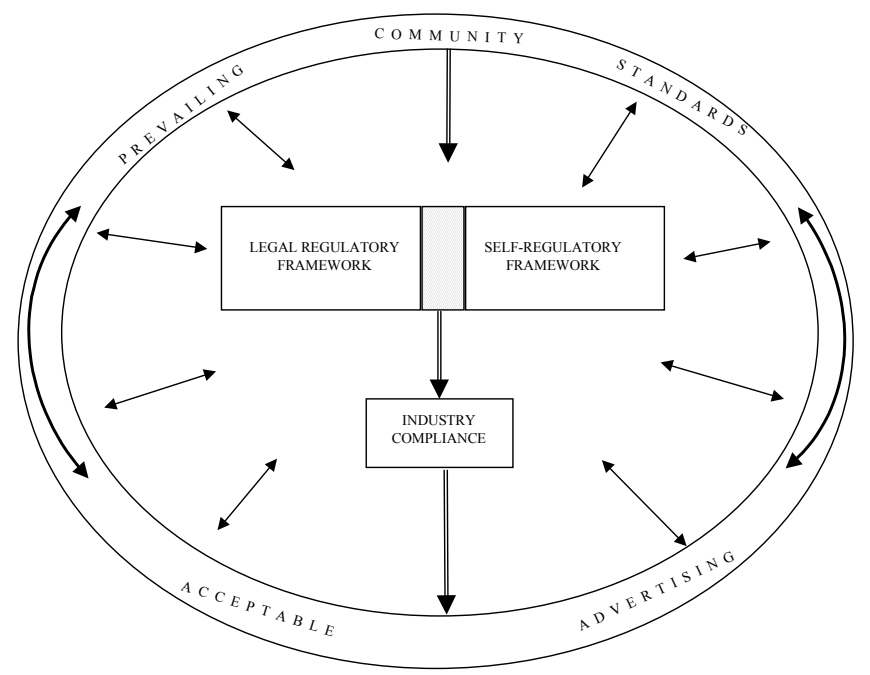

Figure 1: Acceptable advertising: A framework for analysis 
There is a relationship between the relative economic importance of annual advertising expenditure in an economy and the existence or absence of a self-regulatory body concerned with unacceptable advertising (Neelankavil \& Stridsberg, 1980). In other words, the more money spent on the activity in a country, the greater the need for protection from unacceptable advertising. However whilst advertising contributes to a country's economy it must also satisfy the social norms that exist in that country, that is, the activity should be responsible and accountable, providing acceptable advertising to society.

Irrespective of whether they work within a legal or selfregulatory system, advertising regulators must still attempt to define 'acceptability'. Defining any value-laden term such as 'acceptability' is problematic, and this difficulty is exacerbated by the competing interests that enter into debates on advertising. That is, advertisers typically hold the view that, in a free society, they should be permitted to promote their products and services as they wish, provided they do not breach the privileges of free speech (i.e. their messages are not misleading, deceptive or defamatory). Advertising agencies concur with this view, since it allows them to exercise their creative craft freely. Consumers and certain interest groups (such as religious groups, churches, lobby groups) within the public domain believe such freedom needs boundaries. At the heart of any good advertising message is the concept of communication and, whilst the communication process has been studied at length in the marketing literature, the true purpose of any communication must not be overlooked; that is, to transfer 'meaning' from source to receiver. The difficulty that advertisers face, however, is that 'meaning' is subjective; it is internal to the receiver, rather than external (Shimp, 2000) and this has serious implications for those concerned with controlling unacceptable advertising.

Regulators attempt to deal with this issue by considering 'prevailing community standards', by ensuring complaints boards contain representatives from throughout the community, and by publicising their adjudications widely. These measures mean 'acceptability' is defined by default as advertising that did not clearly fall foul of legal or selfregulatory standards. This approach is pragmatic, since regulators must take decisions, but it needs also to be recognised that these decisions are subjective.

Attempts to represent prevailing community standards in an ASR system are usually achieved by involving the public in the complaint handling process, which should lead to increased effectiveness of the program (LaBarbera, 1980:32; Boddewyn, 1983; Armstrong \& Ozanne, 1983:26; Moyer \& Banks, 1977:194; Trade Practices Commission, 1988:53) and also provide a credible and transparent process which is open, frank and candid for all. Some programs also attempt to monitor trends in advertising and community standards as a means of better representing current standards in the community (Canadian Advertising Foundation, 1991).

Involvement from the public can be at two levels; as complainants and also as members of the complaint handling body. Most complaints in most countries originate from members of the public and, as ASR programs are established primarily to protect these people, this situation is healthy. However, there is concern about the growing number of complaints stemming from 'competitors' and 'trade organisations' in countries such as Canada (Boddewyn, 1992) and Australia (Harker, 2000).

There is no 'magic mix' regarding the make-up of a complaint handling body and there is little in the literature to guide us as to what ratio works best. Whatever the mix, the public persons who are involved in determining complaints are generally not 'ordinary people' but rather of the 'great and the good' (Boddewyn, 1983:83) and 'amateur, but often distinguished' (Tunstall, 1983:237). In essence the public members of a complaint handling body are better educated and better known people and, usually, members of the 'Establishment'. However, one might question the appropriateness of such people to represent the prevailing community standards of a society.

The 'fundamental determinant' of a developed or developing country's ASR system is a sound legal regulatory framework which complements the selfregulatory structure (Miracle \& Nevett, 1987 xxii). The legal regulatory framework in this instance refers to the laws and regulations in place to protect society from unacceptable advertising, and also to those bodies charged with implementing the laws and regulations.

The laws and regulations governing advertising practices obviously vary from country to country; however, there are certain areas of commonality that assist in improving the acceptability of advertising at the country level. While much legislation that deals with advertising relates to aspects of consumer protection or regulation of competition (Sverdrup \& Sto, 1992), in most developed countries illegal advertising practices, encompassing 'unacceptable advertising', are governed by laws pertaining to 'marketing' or 'broadcasting' and many countries have umbrella legislation of this kind in place.

There is an important overlap between a country's legal regulatory framework and its advertising self-regulatory framework in relation to advertising. In order for the two frameworks to co-exist effectively many tasks and responsibilities can be delegated to each other, if the system is mature enough. For example, countries which have established a national tripartite system (Boddewyn, 1992:9; Sinclair, 1992:3) whereby the advertisers, agencies and media are involved in the process, the chances of industry compliance with decisions are greatly enhanced as unacceptable advertising will not be published or broadcast by the various arms of the media. However, this aspect of the process was at the heart of Australia's demise in 1996 as the Australian Competition and Consumer Commission (ACCC) found the collusive nature of the practice to be illegal under the original regime.

Whilst many critics of advertising would argue that the advertisers opt for self-regulation as a protection against government intervention, it is this very situation that has assisted in the evolution of the more effective ASR systems. For example, systems such as New Zealand and the UK which do not have the luxury of a tripartite system still 
achieve some success in ensuring that when a complaint about advertising is upheld, the advertiser complies with the ruling and removes or amends the ad.

Achieving industry compliance in an ASR system is vitally important or else the process will be accused of impotence. Compliance is usually achieved through sanctions such as prosecution under law, in the most extreme circumstances, and financial incentives to comply with rulings from charter bodies. Complaint handling bodies achieve varying levels of success in relation to encouraging industry compliance; for example, where an ASR system incorporates a national tripartite system (Boddewyn, 1992:9; Sinclair, 1992:3), as discussed above, compliance is improved as the complaint handling bodies are given 'teeth'.

\section{Applying the framework}

\section{The countries}

The UK has both the fastest advertising spend growth rate in Europe (Advertising Age, 1996) and also the most developed and effective ASR scheme in the world (Boddewyn, 1992:3), often forming the basis for many developing advertising self-regulatory bodies internationally. Australia and South Africa, on the other hand, are not such world players. Australia spent US\$4.8 billion in 1997, representing $1.8 \%$ of world advertising expenditure in 1997, whilst South Africa spent US\$1.3billion in the same period, accounting for $0.5 \%$ of world advertising spend (World Advertising Trends, 1999:10,11). However, both countries have based their ASR systems on that of the UK (the Advertising Standards Authority (ASA UK)).

Whilst, until the end of 1996, the advertising industry in Australia had observed the disciplines of self-regulation for more than sixty years (Australian Advertising Industry Council (AAIC), 1989), their complaint handling body, the Advertising Standards Council, had only been operational for around twenty years (ASC, 1989). After the demise of the old system of ASR in Australia in 1996, the ASR system and effort has been coordinated by the Advertising Standards Bureau (ASB) ${ }^{1}$.

The South African advertising industry has undergone fundamental changes since the 1960s. More specifically, the democratisation of the country in 1994 impacted on every aspect of life. The need to respect freedom of speech whilst at the same time ensuring that the social, cultural and religious freedoms of the diverse groups of the country, present particular challenges with regard to advertising. As a result, the advertising industry faces very specific consumer legislation. In essence, South Africa has opted for a voluntary system of self-regulation, coordinated by the Advertising Standards Authority (ASA SA). However, the regulation is an interesting mix of statutory and selfregulatory measures with a good smattering of constitutional law (Delport, 1999).

\footnotetext{
${ }^{1}$ See Harker, Harker and Volkov (2001) for a commentary on the changing nature of ASR in Australia at this time.
}

Table 1 displays the key variables for comparison.

\section{Prevailing community standards}

Representation of prevailing community standards is usually achieved by involving the public in the complaint handling process; this involvement can be at two levels, as complainants and as members of the complaint determination board.

The UK is seriously concerned with outside participation on the council that adjudicates on complaints. The ASA UK comprises 12 people; two-thirds being 'completely independent', one-third industry (Boddewyn, 1992:125). The UK ASR system operates on the basis that a system 'should be seen as effective', which requires publicity (Miracle \& Nevett, 1987:121).

In Australia, a stand-alone panel determines complaints about taste and decency, traditionally the domain of the general public. The public are also very involved in complaint determination, making up the entire 14-person panel on the Advertising Standards Board, Australia's complaint handling body. The Board recruits members from the worlds of business, media, academe and sport, in other words, 'the great and the good' (Boddewyn, 1983:83).

In South Africa, on the other hand, members of the public may complain about an advertisement but there is no formal mechanism involving them in the complaint process. The complainant is, however, given the opportunity to make a presentation at the ASA SA Committee meeting. Whilst consumer and trade organisations are part of the consultation process of the ASA SA, public representation is not accepted practice. The ASA SA deals with around 1,000 complaints per annum and in recent years the majority of these have been generated from agencies acting on behalf of their clients.

\section{Legal regulatory framework}

The UK, South Africa and Australia share an extensive array of local and national legislation governing broad marketing activities in general and advertising in particular. In all three countries, there exist umbrella bodies that preside over broadcasting on radio and television incorporating advertising (the UK's Broadcasting Act of 1990; Australia's Broadcasting Services Act of 1992; South Africa's Independent Broadcasting Authority Act of 1993; Harker, 1998).

All three countries have similar legislation in place concerned with trade practices, however a key difference between Australia and the other two countries lies in the change-over from the Trades Practices Commission to the Australian Competition and Consumer Commission as the body concerned with monitoring the effectiveness of ASR. Whilst the ACCC was the catalyst that brought about the demise of the MCA and ASC in 1996 (Harker, Harker \& Volkov, 2001), that body now closely monitors the ASB. 


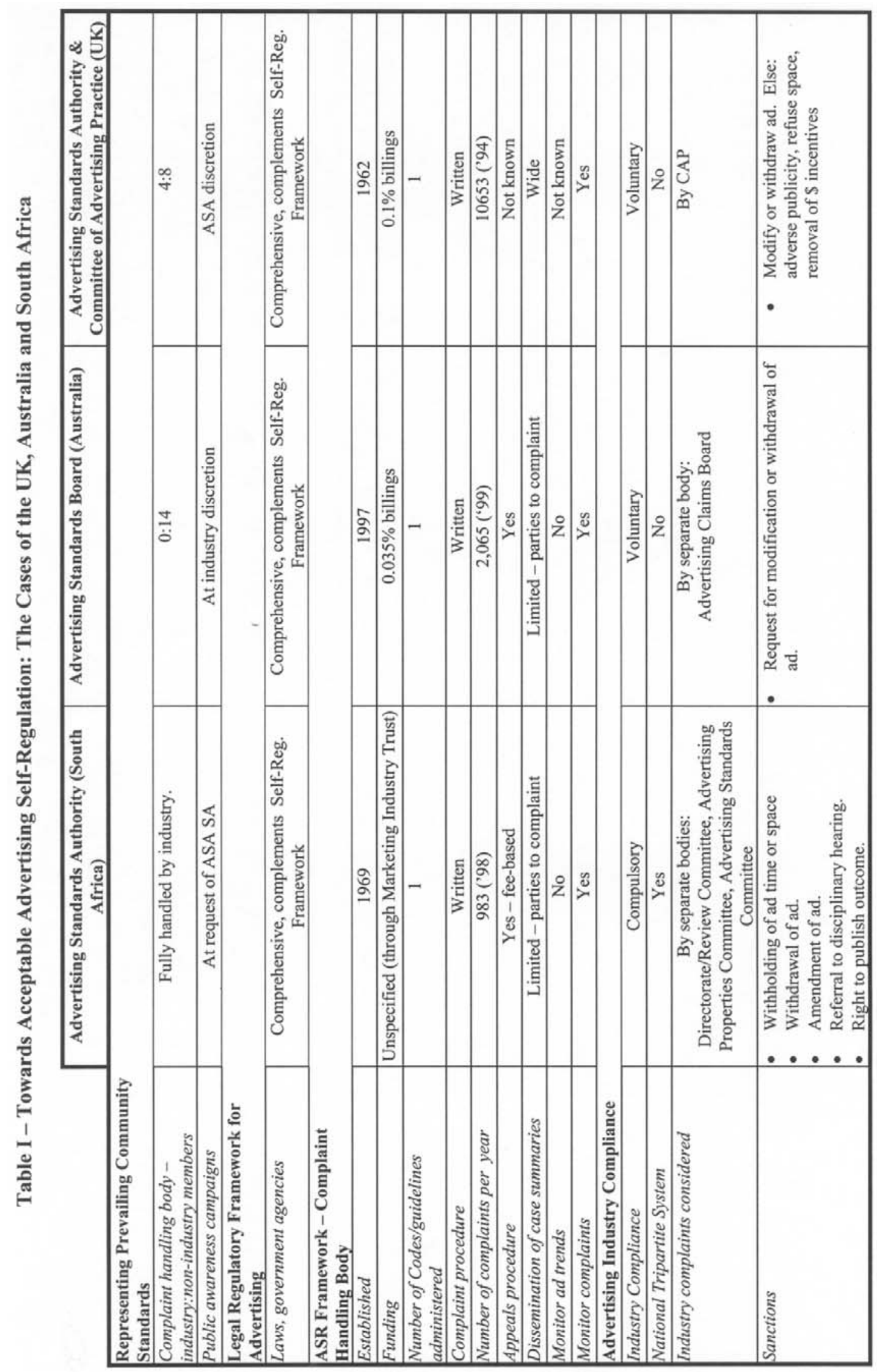


In South Africa there are only two pieces of legislation that make direct reference to advertising practice. These are the Trade Practices Act of 1976 and the Consumer Affairs Act of $1999^{2}$. In addition, there are a further 72 Acts in South Africa that make reference to advertising within specific spheres of activity (Woker, 1999; ASA SA, 1999; Sinclair, 1997).

There have also been moves underway in South Africa to merge the Independent Broadcasting Authority (IBA) and the South African Telecommunications Regulatory Authority (SATRA) (South Afrcian Embassy, 1999). SATRA is an independent organisation that falls under the ambit of the Telecommunications Act No 3 of 1996. SATRA has a broad-based mandate including regulation, services, fair competition and empowerment of disadvantaged communities. The Broadcasting Monitoring and Complaints Committee (BMCC) is a standby committee of the IBA and has been established under sections 21 and 22 of the Independent Broadcasting Authority Act of 1993 (Van Rooyen, 1999; South Afrcian Embassy, 1999; Ministry for Posts, Telecommuniations and Broadcasting, 1997). The purpose of the BMCC is to fulfil the terms and obligations relating to broadcasting licences, the Code of Conduct for Broadcasting and the Code of Advertising Practice. Therefore, the IBA regulations serve to complement the regulations of the ASA SA self-regulating body.

The Consumer Affairs Bill has given government agencies in South Africa the power to investigate all types of advertising (Sinclair, 1997). Although there is no clear inclusion of the self-regulating body (ASA SA) in this Act, the Consumer Affairs Bill complements the stipulations set out in the ASA SA's Code of Practice. In addition to this Act, the Independent Broadcasting Authority Act No. 15 of 1993 was promulgated in 1994 as a provision which directly and indirectly impacts on the freedom of expression (Van Rooyen, 1999; South Afrcian Embassy, 1999; Sinclair, 1997)

One final area of legislation where the countries differ is in relation to laws prohibiting the advertising of tobacco, Australia has a law in place (Tobacco Advertising Prohibition Act 1992), the other two do not.

\section{Advertising self-regulatory framework}

From the business perspective, the threat of government regulation is often a key incentive to self-regulate effectively (Grabosky \& Braithwaite, 1986; Blakeney \& Barnes, 1982; Levin, 1967) and advertisers in the UK, South Africa and Australia are enthusiastic self-regulators.

\section{(a) Australia}

The structure of ASR in Australia can be seen at Figure 2.

The ASA SA was inaugurated in 1969, well before countries such as Australia (1974), New Zealand (1988) and the USA (1971) (Harker, 1998). The industry operates with a Code of Practice that is based on the Code prepared by the International Chamber of Commerce (ASA SA, 1994c).

The ASA SA is an autonomous, non-profit organisation with an independent chairperson to ensure that the system operates in the public interest. It is governed by a Board of Directors, with representatives of all major marketing organisations (such as the Association of Advertising Agencies, Association of Marketers etc), and is staffed by a full time directorate (ASA SA, 1999; Sinclair, 1997).

Although a committee drawn from constituent member bodies administers the Code, powers of interpretation are vested in the ASA SA Review Committee and subsequently, the Standards Committee and the Properties Committee, that deal with complaints.

The ASA SA is financed by the advertising industry by way of a levy on advertising spend. The levy is determined by the exposure to measured media and administered through the Marketing Industry Trust (ASA SA,1999). Fees are also charged for an appeal. Complainants and the respondent are required to lodge a sum of money determined by the ASA SA, and competitors not represented by an advertising agency are also required to pay an administrative fee determined by the ASA SA. Complaints from the public carry no charge.

The ASA SA stipulates a pre-clearance procedure for all advertisements which must be screened prior to being carried in the media, this function is performed by the Association for Advertising Agencies Advisory Service (ASA SA, 1994c).

Investigations by the ASA SA are only commissioned upon receipt of a written complaint with details of the advertisement. The complaints are handled in the first instance by the Review Committee/ Directorate beyond which they may be handled by the Advertising Standards Committee and the Advertising Properties Committee.

\section{(b) The United Kingdom}

The structure of ASR in the United Kingdom can be seen at Higure 4.

The Advertising Standards Authority (ASA UK) is a limited company and was established in 1962, making it a 'mature' body (Neelankavil \& Stridsberg 1980:xxi), with the prime objective of ensuring that all non-broadcast advertisements which appear in the UK are legal, decent, honest and truthful (ASA UK, 1994a). The ASA UK does not handle complaints from competitors, rather they are directed to the Committee for Advertising Practice (CAP). The CAP consists of representatives of twenty-three advertising organisations, including advertisers, agencies and all types of media. The ASA UK and CAP share the same premises in London, the Secretariat with 60 staff, and chief executive (Boddewyn 1992; ASA UK 1994b).

${ }^{2}$ Formerly known as the Harmful Business Act 71 of 1988. 


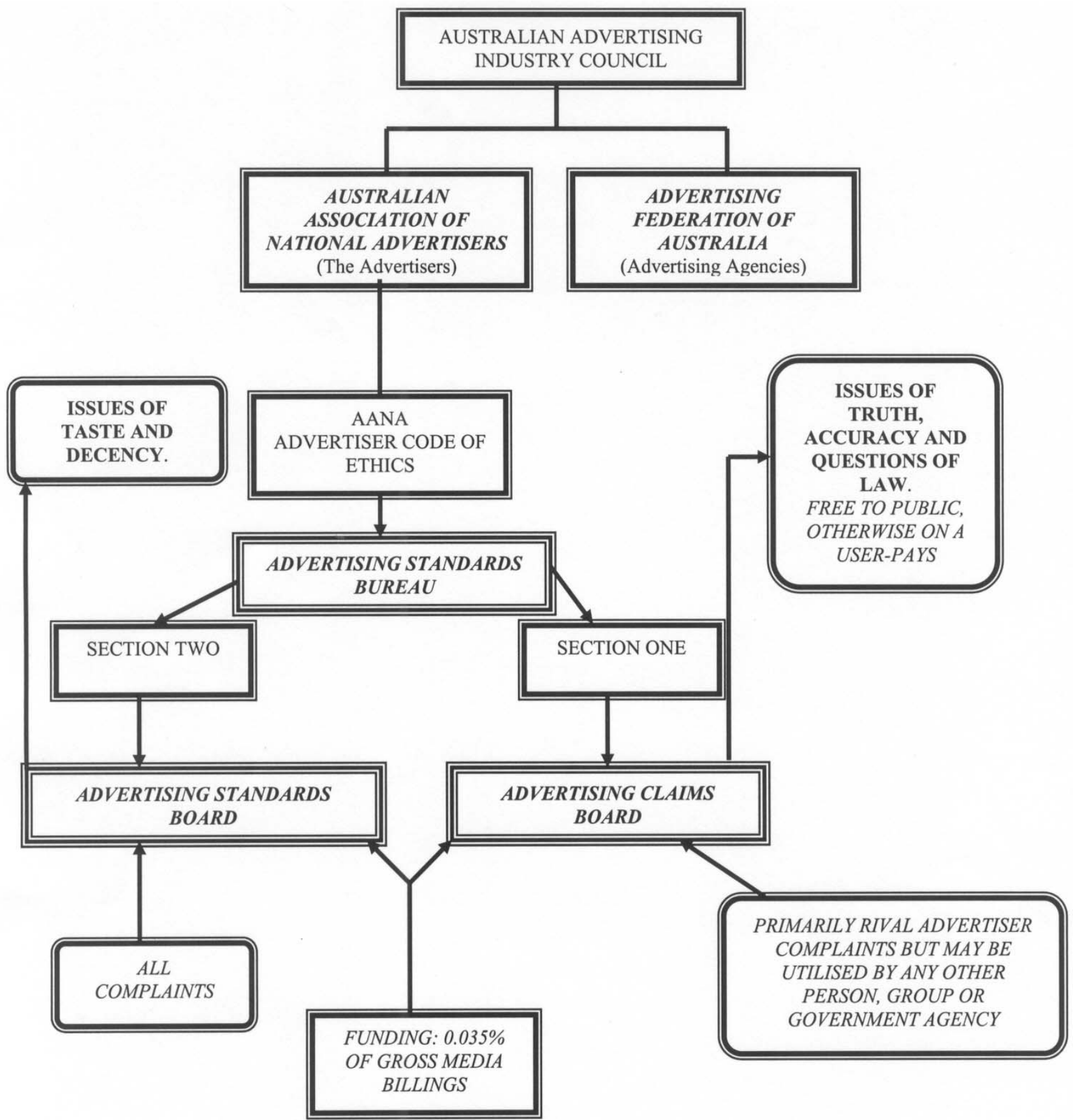

(Source: Harker, Harker and Volkov 2001)

Figure 2: The structure of advertising self-regulation in Australia 


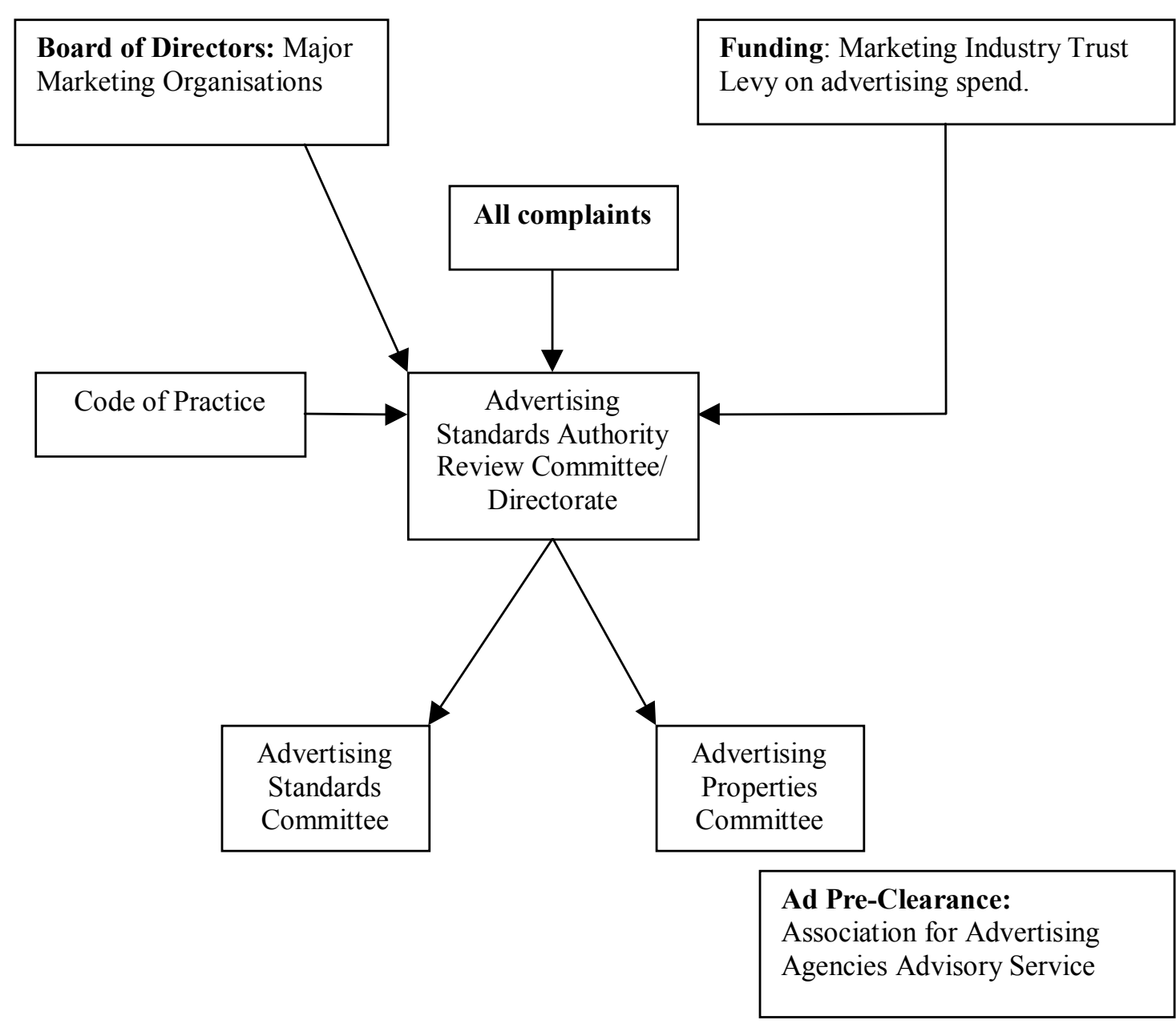

Figure 3: The structure of advertising self-regulation in South Africa

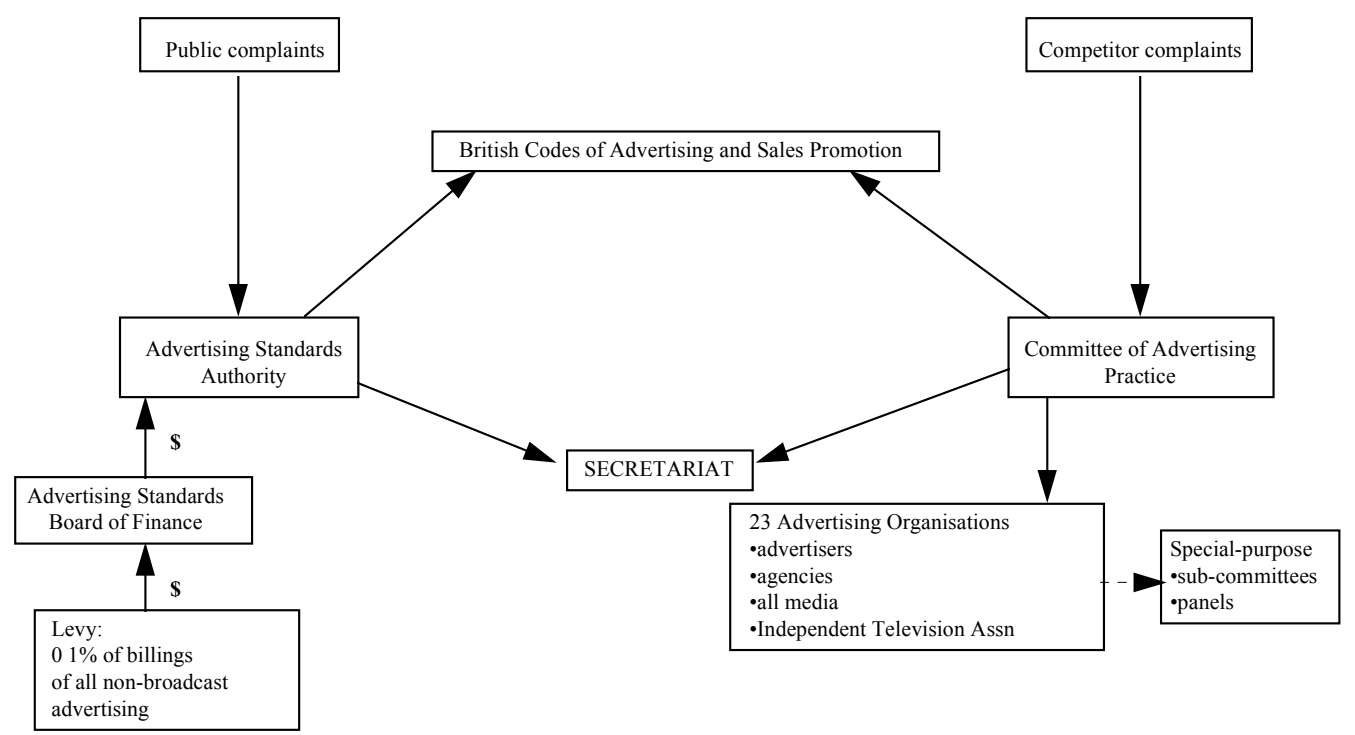

Figure 4: The structure of advertising self-regulation in the United Kingdom 
The ASA UK is funded by a $0.1 \%$ levy on billings on all forms of non-broadcast advertising (Boddewyn, 1992) and the Advertising Standards Board of Finance was established to collect these funds in order to preserve the ASA UK's independence (ASA UK, 1994a).

In terms of the ASR framework, and in particular the complaint handling bodies, all three systems operate in a similar precedential manner. All three require a complaint to be in writing and this in itself is problematical for the illiterate, poorly educated and inarticulate members of society who, nevertheless, have a fundamental right to complain. Given the different level of development in each country, this situation is probably more of a concern for South Africa than Australia at this moment in time.

Whilst the majority of complaints made about advertising around the world originate with the public, an increasing number come from industry sources (Boddewyn, 1992; Harker, Harker \& Volkov, 2001). The implications of this trend being that the system that segregates rival advertiser complaints, and perhaps opts for a 'user-pays' system, will be more effective in generating only those rival advertiser complaints that are for serious consideration, rather than frivolous. Also such a system would allow appropriate time for consideration of complaints from other sources, such as the general public. This approach is evident in all three countries and, to date, Australia's Advertising Claims Board (for rival advertisers) has not been required to meet (Fraser, 1999).

\section{Industry compliance}

Compliance by the advertising industry with rulings from the complaint handling body is a key component of any ASR system. It was suggested earlier that, where the ASR scheme incorporates a national tripartite system (Boddewyn, 1992:9, Sinclair, 1992:3) and the advertisers, agencies, and media are involved in the process, the chances of industry compliance with rulings are greatly enhanced as the complaint handling bodies are given 'teeth'.

Whilst the UK does not have the luxury of a tripartite system of media control, industry compliance with ASA UK rulings is distinctly 'enforceable'. If an advertisement is found to be 'unacceptable' (ASA UK, 1994a:3), that is in breach of the Code, the advertiser is requested to change or remove it; failure to do so could lead, ultimately, to prosecution through the Office of Fair Trading under the Control of Misleading Advertisements Regulations 1988 (ASA UK, 1994a). However, this ultimate sanction is rarely used.

Australia's ASB relies on the goodwill of recalcitrant advertisers to toe the line. Indeed, Australia has had its first 'real' test of the voluntary nature of its compliance process and was found wanting. Outdoor advertising for WindsorSmith shoes, depicting a man cradling a woman's face close to his groin (Mckenzie, 2000), caused public outcry in early 2000 with the National Women's Media Centre in Queensland calling on women to boycott sex with men who wore the brand of shoe (Mckenzie, 2000). The ASB upheld complaints about the advertisement but Windsor-Smith refused to remove the ad (Mckenzie, 2000). Eventually the billboard owner took down the ad.

South Africa enjoys the advantages of compulsory compliance through its national tripartite system. The IBA Act stipulates that the ASA SA administer the Code applicable to advertising and the BMCC will administer the Code applicable to broadcasting, although the BMCC has jurisdiction over the Advertising Code of Practice. The ASA SA has, however, the support and backing of 22 member organisations comprising the major advertisers (Association of Marketers), the advertising agencies (Association of Advertising Agencies) and the major media networks (ASA SA, 1999; Woker, 1999). This tripartite membership delivers industry compliance. The power to secure compliance resides in the following sanctions that may be imposed:

- The withholding of advertising time or space.

- Withdrawal of the advertisement.

- Amendment of the advertisement (usually within seven days).

- Referral to a disciplinary hearing.

- The right to publish the outcome of the investigations.

An appeals process is in place which guards against the outright rule of the ASA SA.

\section{Summary and conclusions}

This article articulated two objectives: first, to present and discuss the key variables associated with acceptable advertising. Second, to use these variables as a framework to analyse the way advertising is regulated in the UK, Australia and South Africa with a view to improving the effectiveness of ASR in all countries.

All three countries have a legal regulatory framework that complements the self-regulatory framework, and in each case the two variables work together. It must be emphasised, however, that the self-regulatory scheme is a key variable in this framework. Whilst there are many similarities between the countries in terms of the types of laws in place to regulate advertising, it is apparent that establishment of a sound, committed, and supportive selfregulatory framework enhances the legal environment.

Whilst each country's advertising self-regulation system is funded in the same way, by a proportion of billings, the South African percentage is smaller than the UK and Australia's (the ASA SA gets less than $5 \%$ of the levy), however it should be noted that South Africa's ASA SA handles around half of the number of complaints that the Australian system handles. Funding is admittedly, a vitally important component of an effective advertising selfregulation program. Indeed the lack of sufficient funds had a serious impact on the demise of the Australian system (Harker, 1997). This is particularly relevant in the South 
African situation, where the ASA SA was under threat to disband due to a lack of funding in 1996.

Whilst all of these three schemes try to achieve industry compliance through their advertising self-regulation schemes, where the scheme incorporates a national tripartite system (Boddewyn, 1992:9; Sinclair, 1992:3) and the advertisers, agencies and media are involved in the process, the chances of compliance are greatly enhanced as the complaint handling bodies are given 'teeth'. The three countries studied here are quite different in this regard as South Africa achieves compliance with its national tripartite system, whilst the UK and Australia operate under a voluntary regime. The paradox here being that the UK functions effectively in this regard, whilst Australia's system has been found wanting.

In terms of public representation on the $\mathrm{CHB}$, Australia and the UK put the balance soundly in favour of the public, however, in South Africa, there seems to be a complete lack of public representation. In the five-country study by Harker (1998), the UK has the most sophisticated system of two way communication with its public while America, like South Africa, keeps a very low public profile in its complaint handling process.

Recommendations for Further Research

From this analysis three key areas emerge for researchers to study. The first area relates to the voluntary nature of industry compliance in Australia specifically. Only time will tell if the ASB can make a virtue out of this necessity and draw on the unwritten support of the various media bodies to assist the self-regulatory system evolve. Regulators must, however, learn from the Windsor-Smith example and seek (albeit unwritten) commitment from the stakeholders in order to ensure industry compliance. Australia can learn from South Africa and the UK in this regard.

The second area relates to the issue of 'enlightened selfinterest' and is concerned with the fact that the advertisers are, to all intents and purposes, paying for and running the ASR system's in all three countries, so how can we be sure, as societies, that they are acting in our best interests and not their own? Or, worse still, will our systems of ASR merely have as Ducret (1991) warns, the lunatics finally in charge of the asylum?

Finally, there is a need for future research into the representation of prevailing community standards as, generally, there appears to be little creativity amongst the ASR systems in operation around the world in this regard. From this study, it appears that South Africa can learn from the Australian model of ASR and both of these can learn from the UK which has established methods. However there is also an opportunity for all three to learn from those bodies around the world that do go further than merely including members of the public onto the complaint handling body and accepting public complaints. Canada, for example, monitors trends in what people are complaining about and also the trends in advertising itself, highlighting new developments for the attention of its complaint handling body (Canadian Advertising Foundation, 1991).
We have an opportunity to develop best practice ASR, starting with the reformulation of the Australian scheme. Further studies of other ASR schemes, both from around the world, will assist this development.

\section{References}

Advertising Age International, 21, August, 1996. 'Worldwide ad spend up 8.9 percent to \$270bn'. [online] URL: http//:www.adage.com/nssearch/international

Advertising Standards Authority Ltd. 1994a. Advertising under control. London: ASA.

Advertising Standards Authority Ltd. 1994b. Annual Report, ASA London.

Advertising Standards Authority. 1994c. Code of advertising practice. Durban: Butterworths.

Advertising Standards Authority. 1999. Review. South Africa: ASA SA.

Advertising Standards Bureau. 1999. Annual Report. Sydney, Australia: ASB.

Advertising Standards Council. 1989. Sydney: ASC Charter.

Armstrong, G. M. \& Ozanne, J. L. 1983. 'An evaluation of NAD/NARB purpose and performance', Journal of Advertising, 12(3): 15-52.

Australian Advertising Industry Council. 1989. Advertising: Consumers have their say. Sydney: AAIC.

Australian Association of National Advertisers. 1993. Advancing the interests of advertisers. Sydney: AANA.

Baker M. J., Graham, P., Harker, D. \& Harker, M. 1998. Marketing: Managerial foundations. Sydney: Macmillan.

Best, B. 1997. 'International business and ethics: The role for ethical displacement,' Business and the Contemporary World, 9(1): 209-227.

Blakeney, M. \& Barnes, S. 1982. 'Advertising regulation in Australia: An evaluation', The Adelaide Law Review, 8(1): 29-60.

Boddewyn, J. J. 1983. 'Outside participation in advertising self-regulation: The case of the Advertising Standards Authority (UK)', Journal of Consumer Policy, 6: 77-93.

Boddewyn, J. J. 1985. 'Advertising self-regulation: Private government and agent of public policy', Journal of Public Policy and Marketing, 4:129-141.

Boddewyn, J. J. 1988. Advertising self-regulation and outside participation: A multinational comparison. Connecticut: Quorum Books.

Boddewyn, J. J. 1989. 'Advertising self-regulation: True purpose and limits', Journal of Advertising, 18(2): 19-27. 
Boddewyn, J. J. 1992. Global perspectives on advertising self-regulation. Westport, Connecticut: Quorum Books.

Canadian Advertising Foundation. 1991. Canadian code of advertising standards. Canada: CAF.

Delport, P. 1999. 'Legal, decent, and truly unique'. [online] URL: (www.directorsearch.com)

Drake, R. 1988. 'The portrayal of women in advertising', Consuming Interest, December: 21.

Ducret, A. 1991. 'Deregulation and the Trade Practices Act,' In Head, B \& McCoy, E. (Eds.). Deregulation or better regulation?: Issues for the public sector. Australia: Macmillan, pp.70-79.

Fraser, H. 1999. Personal communication with Chief Executive-Past, Advertising Standards Board, Sydney.

Freedom of Commercial Speech Trust. 1999. 'Freedom of commercial speech'. [online] URL: www.users.iafrica.com/f/fc/fcstrust.

Grabosky, P. \& Braithwaite, J. 1986. Of manners gentle: Enforcement strategies of Australian business regulatory agencies. Australia: Oxford University Press.

Gupta, A. K. \& Lawrence, J. L. 1983. 'Industry selfregulation: An economic organisational and political analysis,' Academy of Management Review, 8(3):416-425.

Harker, D. 1998. 'Achieving acceptable advertising: An analysis of advertising regulation in five countries,' International Marketing Review, 15(2): 101-118.

Harker, D. 1997. 'The control of advertising in New Zealand and Australia: Learning from success and failure,' Policy Organisation and Society, Winter 14:57-81.

Harker, D. 2000. 'Complaints about advertising: Whats really happening?' Qualitative Market Research: An International Journal, 3(4): 198-206.

Harker, D., Harker, M. \& Volkov, M. 2001. 'Developing effective advertising self-regulation in Australia: Reflections on the old and new systems,' Australasian Marketing Journal, 9(1): 7-19.

Harris, R. G. \& Carman, J.M. 1983. 'Public regulation of marketing activity. Part I: Institutional typologies of market failure,' Journal of Macromarketing, Spring:49-58.

Harris, R. G. \& Carman, J.M. 1984. 'Public regulation of marketing activity. Part II: Regulatory responses to market failures', Journal of Macromarketing, Spring:41-52.

Internet (1995) Advertising Self-Regulation, The Better Business Bureau Web Server, June 8th.

Jewell, L. \& Reitz, H.J. 1981. Group effectiveness in organizations. New York: Scott Foresman.
LaBarbera, P. A. 1980. 'Analyzing and advancing the state of the art of advertising self-regulation', Journal of Advertising, 9(4): 27-38.

Levin, H. J. 1967. 'The limits of self-regulation', Columbia Law Review, 67(4): 603-643.

Mckenzie, A. 2000. 'Ads behaving badly', The Weekend Australian, March, 25-26: 27.

Media Council of Australia. 1996. Media release, September 27 , Sydney.

Ministry for Posts, Telecommunications and Broadcasting . 1997. A Green Paper for Public Discussion. Pretoria: Ministry for Posts, Telecommunications and Broadcasting.

Miracle, G. E. \& Nevett, T. 1987. Voluntary regulation of advertising: A comparative analysis of the UK and US. Mass., US: D C Heath.

Mittal, B. 1994. 'Public assessment of TV advertisements: Faint praise and harsh criticism', Journal of Advertising Research, 34(1): 35-53.

Moyer, M.L. \& Banks, J.C. 1977. 'Industry self-regulation: Some lessons from the Canadian advertising industry'. In D. Thompson, D (Ed.). Problems in Canadian marketing, Chicago AMA, pp. 185-202.

Neelankavil, J. P. \& Stridsberg, A. B. 1980. Advertising self-regulation: A global perspective. New York: Communications Arts Books.

Ofner, J. 1959. 'Are committees worthwhile?' Commerce Magazine, 56(2):64-65.

Shimp, T. A. 2000. Advertising promotion: Supplemental aspects of integrated marketing communications. $5^{\text {th }}$ Edition. New York: The Dryden Press.

Sinclair, R. 1997. The South African advertising book: Making the other half work to., $4^{\text {th }}$ Edition. South Africa: Thompson Publishers.

Sinclair, J. 1992. 'Globalisation and national culture: Structure regulation and content in the advertising industry in Australia', Policy Research Paper No. 24. Centre for International Research on Communication and Information Technologies. Melbourne: CIRCIT.

South African Embassy Washington. 1999. Media Yearbook. South African Embassy, U.S.A.

Streeck, W. \& Schmitter, P. C. 1985. Private interest government: Beyond market and state. Beverly Hills: Sage.

Strickland, K. 1996. 'Tasteless ads code to vanish', The Australian, Sydney September 28-29:5.

Sverdrup, S. G. \& Sto, E. 1992. 'Regulation of sex discrimination in advertising: An empirical inquiry into the Norwegian case', Journal of Consumer Policy, 14: 371-391. 
Trade Practices Commission. 1988. Industry codes of practice - A brief report. Canberra: AGPS.

Tunstall, J. 1983. The media in Britain. London: Constable.

Van Rooyen, K. 1999. 'Press and broadcasting freedom in a new South Africa', Communication, 20(2). Unisa online journals, available at:

www.unisa.ac.za/dept/press/comca/202/vanrooy html

Wiggs, G. 1992. 'Self-regulation - A mix of judicial and marketing principles'. Unpublished essay, Advertising Standards Complaints Board, New Zealand.

Woker, T. 1999. Advertising law in South Africa. Kenwyn, South Africa: Juta \& Co.

World Advertising Trends. 1999. NTC Publications, Henleyon-Thames, Oxfordshire, United Kingdom.

Wotruba, T. R. 1997. 'Industry self-regulation: A review and extension to a global setting', Journal of Public Policy and Marketing, 16(1):38-54.

Crisis at Advertising Standards Authority. 1996.[Online] URL www fm.co.za. 